\title{
Flotation of barium sulfate contaminants soils
}

\begin{abstract}
Application of flotation for the removal of hydrophilic barium sulfate $\mathrm{BaSO} 4$ compounds from soil was studied. Micro-flotation tests were conducted on artificially contaminated soil, using a mechanically agitated machine. Flotation parameters tested include collector type and dosage, conditioning time, flotation time and pulp $\mathrm{pH}$. It was found that, with single stage flotation, $85 \%$ removal of the contaminant was achieved from soil particles in the range of $80-100 \mu \mathrm{m}$ Flotation was found to have considerable potential for cleaning up contaminated; by combining attrition up to $95 \%$ of contaminant barium sulfate was achieved.
\end{abstract}

Keywords: flotation, soil cleaning, remediation, surfactant, barium
Volume 2 Issue I - 2018

\author{
NS Labidi \\ Department of Materials Sciences, University Centre of \\ Tamanrasset, Algeria
}

\begin{abstract}
Correspondence: NS Labidi, Department of Materials Sciences, Institute of Science and Technologies, University Centre of Tamanrasset, BP (10034) Sersouf-Tamanrasset-I I000, Algeria, Email Labidi19722004@yahoo.fr
\end{abstract}

Received: January 24, 2018 | Published: February 15, 2018

\section{Introduction}

Flotation is, doubtless, the most important process among the various techniques used for the treatment of ore. This general-purpose technique allows the treatment of several complex ores (lead - zinc, copper - zinc), sulphides (copper, lead, and zinc), oxides (hematite, quartz), oxidized minerals (malachite, cerusite) and even non-metal ores (fluorite, phosphate, coal). Due to the flotation, it is possible to concentrate in an economic way poor ores the treatment of which would not be profitable by using other techniques of treatment. ${ }^{1-3}$

Flotation is a physic-chemical process in which one constituent can selectively be separated from another on the basis of surface properties. This is achieved by controlled additions of chemical reagents at predetermined $\mathrm{pH}$, thereby selectively altering the surface characteristics of barium sulfate $\mathrm{BaSO}_{4}$ compounds contaminated soils. Phase separation is then followed by passing air through reagentized slurry. Air bubbles selectively attach to barium contaminated soil particles and are levitated to the surface in the form of froth. The separation of soil particles contaminated with barium sulfate $\mathrm{BaSO}_{4}$ compounds thus renders the remaining soil clean. ${ }^{4-5}$ As flotation is a promising method for the removal of hydrophilic minerals compounds from soil, the role of many relevant parameters in soil decontamination is largely unknown. As a result the objective of this study was to test the feasibility of the flotation process for the removal of barium sulfate $\mathrm{BaSO}_{4}$ compounds from contaminated soils and to investigate the effect of basic parameters such as conditioning and flotation time, surfactant dosage, pulp $\mathrm{pH}$.

\section{Materials and methods}

\section{Soil preparation}

The soil used in this study was obtained from a mining company (ENOF, Algeria). The sample was treated with a solution of $\mathrm{H}_{2} \mathrm{SO}_{4}$ at $13 \%$, washed, dried and calcined at $700^{\circ} \mathrm{C}$. Detailed of the chemical composition of the sample is given in Table 1. The particle size distribution of the sample used for flotation tests was determined by sieving for $10 \mathrm{~min}$ a sample of $500 \mathrm{~g}$ taken from the ground product for screen analysis (Table 2). The soil sample was then artificially contaminated by mixing it with barium sulfate $\mathrm{BaSO}_{4}$ dissolved in deionized distilled water. This barium sulfate was chosen because of its extremely low solubility and high purity. The low solubility minimizes losses by dissolution during the flotation process, and ensures barium-contaminated soil samples, the desired amounts of soil and barium were first weighed and then a pulp of soil and barium dissolved in deionized distilled water and stirring for 30 minutes before flotation. The mixture of barite and soil after contamination was $1 \%{ }^{6}$

Table I Chemical composition of the soil sample

\begin{tabular}{lllllllll}
\hline Elements & $\mathrm{SiO}_{2}$ & $\mathrm{Al}_{2} \mathrm{O}_{3}$ & $\mathrm{MgO}$ & $\mathrm{Na}_{2} \mathrm{O}$ & $\mathrm{Fe}_{2} \mathrm{O}_{3}$ & $\mathrm{CaO}$ & $\mathbf{K}_{2} \mathrm{O}$ & $\mathrm{TiO}_{2}$ \\
\hline$\%$ & 65.2 & 17.25 & 3.1 & 2.15 & 2.1 & 1.2 & 0.6 & 0.2 \\
\hline
\end{tabular}

Table 2 Particles size distribution of the soil sample

\begin{tabular}{ll}
\hline Size range & Weight (\%) \\
\hline$>100 \mu \mathrm{m}$ & 3.55 \\
$100-80 \mu \mathrm{m}$ & 19.45 \\
$80-60 \mu \mathrm{m}$ & 23.98 \\
$60-40 \mu \mathrm{m}$ & 19.96 \\
$40-20 \mu \mathrm{m}$ & 18.54 \\
$20-10 \mu \mathrm{m}$ & 9.72 \\
$<10 \mu \mathrm{m}$ & 4.8 \\
\hline
\end{tabular}

\section{Reagents}

The barium sulfate contaminant used in this study was obtained from a mining company (mine of Ain-mimmoun Khenchela, Algeria). The purity of the sample was analyzed both by XRD, and by chemical analyses. The purity of the samples was founded to be $99.13 \%$. Detailed of the chemical composition of the sample is given in Table 3. Oleic acid (OA 99\%), terpinol (frother) and purchased from ACS. (Algerian Chemical Society) was used throughout the experiments. Freshly prepared oleic acid solutions were used in all the experiments. Dilute solutions of $\mathrm{HCl}$ and $\mathrm{NaOH}$ were used to adjust the $\mathrm{pH}$ of pulp suspension. Tap water was used throughout the study.

Table 3 Chemical composition of the barium sample

\begin{tabular}{llll}
\hline$\% \mathrm{BaSO}_{4}$ & $\% \mathrm{CaO}$ & $\% \mathrm{MgO}$ & $\%_{2} \mathbf{O}_{3}$ \\
\hline 99.13 & 0.34 & 0.31 & 0.22 \\
\hline
\end{tabular}

\section{Zeta potential measurements}

Zeta potential is an indicator of the surface charge of particles, these measurements indicate charge properties of barium and soil particles and in turn can suggest what can adsorb, penetrate, and adhere on particles surface. About $1 \mathrm{gm}$ of $-100 \mu \mathrm{m}$ for each sample 
was suspended in $100 \mathrm{ml}$ of distilled water. The ionic strength of the suspension was adjusted to $10^{-3} \mathrm{M}$ by addition of $0.1 \mathrm{~g}$ of $\mathrm{KNO}_{3}$. The container was inverted 10times and the suspension was allowed to settle for 10 minutes. $60 \mathrm{ml}$ of the supernatant, containing the fine particles, was further aged for two hours before electrophoresis mobility measurements were conducted. The $\mathrm{pH}$ of the slurry was adjusted using dilute $\mathrm{HNO}_{3}$ and $\mathrm{NaOH}$ and was determined before and after the zeta potential measurement using a $\mathrm{pH}$ meter and glass electrode jeanway $3300 \mathrm{pH}$ meter. Zeta potential values were then measured and the values reported are the average of ten readings. ${ }^{8-10}$

\section{Flotation tests}

The objective of these experiments was to establish the optimum $\mathrm{pH}$ and collector dosage required for separation of substitute barium sulfate from soil matrix. One 1 gram of barium sulfate was conditioned in deionized water for 5 minutes before $\mathrm{pH}$ adjustment was carried out. After $\mathrm{pH}$ adjustment, required amounts of sodium oleate were added and the sample was further conditioned for 3 minutes. The sample was then quickly transferred to the flotation cell. Three drop of terpinol was added. Flotation was carried out for about 3 minutes. The float and tailings were filtered, dried, weighed and the weight percent recovery was calculated. ${ }^{7}$

\section{Results and discussion}

\section{Surface charge measurements}

Figure 1 shows the effect of $\mathrm{pH}$ on the surface charge of the barite mineral. The point of zero charge (PZC) of barite is around $\mathrm{pH}$ 5.2. At $\mathrm{pH}$ above 5.2, the surface will be negatively charged, and below $\mathrm{pH}$ 5.2 the surface will be positively charged. Since the soil particles are also negatively charged above $\mathrm{pH} 5.2$, surface active reagents can be used which will selectively and preferentially adsorb barium particles and make them hydrophobic..$^{8-10}$

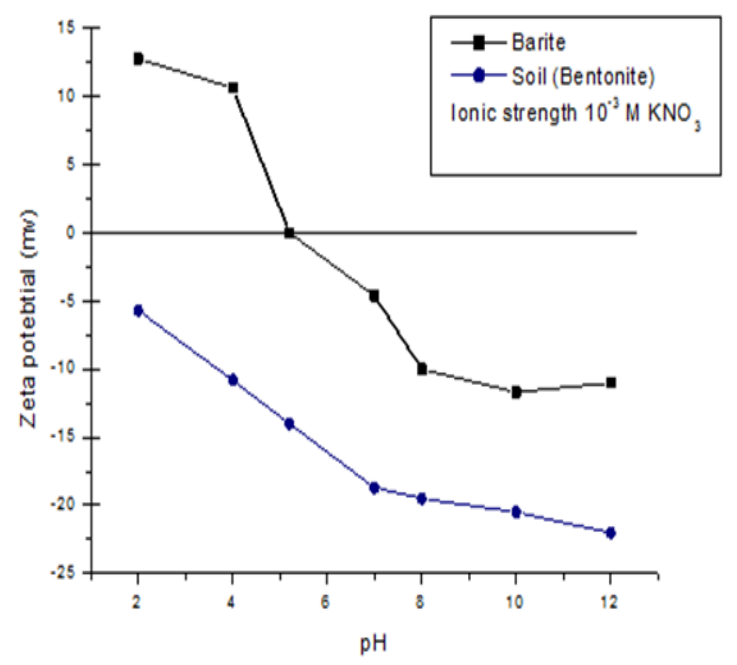

Figure I Zeta potential of barite and soil particles as a function of $\mathrm{pH}$. (Ionic strength maintained by addition of 10-3 M KNO3).

\section{Effect of collector concentration}

In this series of tests, the concentrations of three reagents (sodium oleate, sodium dodecyl sulfonate and sodium laurate) were evaluated Figure 2. It was found that by increasing the concentration of the collectors, the recovery of barite was increased. It is also evident that the percent removal is strongly dependent on the concentration of the surfactant. An increase in length of the non-polar part of the collector should lead to an increase in its adsorption at interfaces and therefore its separation increased. The length of the hydrocarbon chain of the surfactant was found to affect the flotation of barite. ${ }^{11-14}$

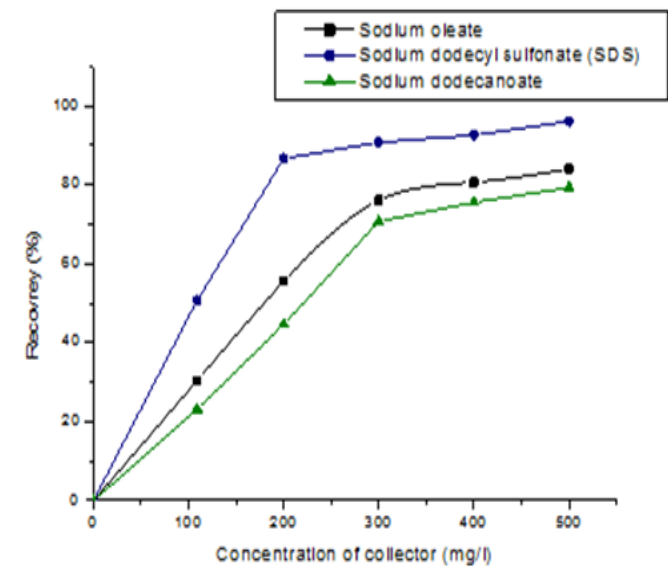

Figure 2 Effect of concentration of collector on barite flotation

\section{Effect of $\mathrm{pH}$}

Pulp $\mathrm{pH}$ plays an important role in the fatty acid flotation of barite. The $\mathrm{pH}$ controls the dissociation of fatty acid, the distribution of acid/ soap species in solution, and the interfacial properties of the flotation system. The effect of high solids conditioning $\mathrm{pH}$ was studied in relation to three reagents (sodium oleate, sodium dodecyl sulfonate and sodium laurate) and barite flotation recovery. The results are presented in Figure 3. At the concentration of collector of 100(mg/l), sodium laurate showed increased recoveries from a value of $15 \%$ at $\mathrm{pH} 2$ to $65 \%$ at $\mathrm{pH} 9.5$ and decreased at high $\mathrm{pH}$. This could be due to the precipitation of the sodium laurate at high $\mathrm{pH}$. However; Sodium oleate and sodium dodecyl sulfonate(SDS), on the other hand, did not show appreciable change in the recovery values in the $\mathrm{pH}$ range $2-12$; and the recovery value was maintained at around the $85 \%$ level. From these results it can be concluded that sodium oleate and sodium dodecyl sulfonate (SDS) are an effective collector's for recovering barite. On the other hand, sodium dodecanoate is sensitive to the $\mathrm{pH}$ of the solution. ${ }^{15}$

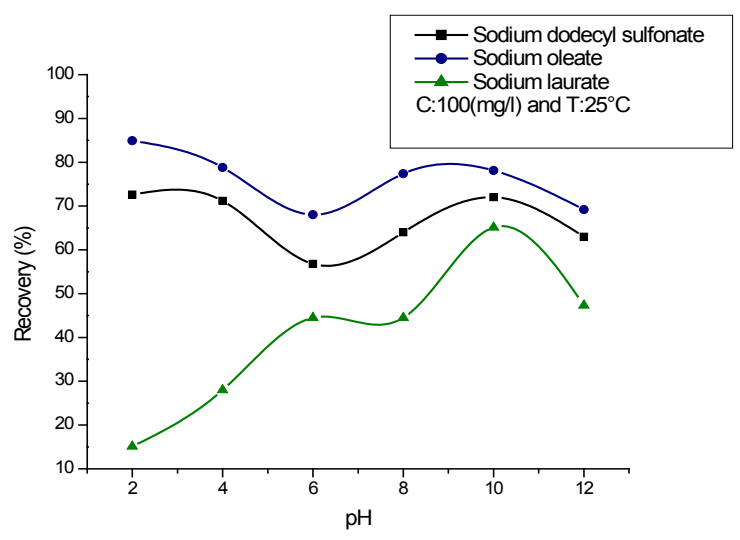

Figure 3 Effect of $\mathrm{pH}$ on barite flotation with sodium oleate, sodium dodecyl sulfonate and sodium laurate. $\left(\mathrm{C}=100 \mathrm{mg} / \mathrm{l}, \mathrm{T}=25^{\circ} \mathrm{C}\right)$. 


\section{Conclusion}

The feasibility of barium elimination from artificially contaminated soil by flotation has been demonstrated. Effects of three types of surfactants (sodium oleate, sodium dodecyl sulfonate and sodium laurate) and their dosage, pulp $\mathrm{pH}$, surface charge measurements were determined. With flotation process over of an $85 \%$ barium sulfate removal can be achieved for the $80-100 \mu \mathrm{m}$ soil fraction, using oleic acid as collector at acidic medium $\mathrm{pH}=4$ or alkaline medium $\mathrm{pH}=9.5$ and terpinol as frother.

\section{Acknowledgements}

I gratefully acknowledge the support of this work by the Department of Materials Sciences, Tamanrasset University Centre, Algeria.

\section{Conflict of interest}

Author declares there is no conflict of interest in publishing the article.

\section{References}

1. Griffiths RA. Soil-washing technology and practice. Journal of Hazardous Materials. 1995;40(2):175-189.

2. Sabatini DA, Knox RC, Harwell JH. Surfactant-Enhanced Subsurface Remediation. Emerging Technologies, ACS Symp. 1995. p. 594.

3. Gaudin AM. Flotation. Mc Graw Hill Co, New York, USA; 1957.

4. Somasundaran P. Advances in Mineral Processing. Soc. Mining Engin, New York, USA; 1986.

5. Wllichowski M. Applicability of flotation in the washing of soil. Chemlng Tech. 1995;67:760.
6. Jones MH, Woodcock JT. Principles of Mineral Flotation. The Australasian Institute of Mining and Metallurgy. Victoria, Australia; 1984. p. 132.

7. Wills BA. An Introduction to the Practical Aspects of Ore Treatment and Mineral Recovery. Mineral Processing, Pergamon Press, UK; 1992.

8. Lima RFS, Brandlo PRG, Matsuoka I. Zeta-potential of synthetic chromite-related spinels: Calculated and measured values. In Proc. of the Sixth International Congress on Applied Mineralogy. Germany; 2000. p. 175-178.

9. Churaeva NV, Ralstonb J, Sergeevaa IP, et al. Electrokinetic properties of methylated quartz capillaries. Advances in Colloid and Interface Science. 2002;96(1-3):265-278.

10. Purohit P, Somasundaran P, Kulkarni R. Study of properties of modified silicones at solid-liquid interface: Fabric-silicone interactions. Journal of Colloid and Interface Science. 2006;298(2):987-990.

11. Mohal BR. Micro flotation Studies of Hexadecyl Sulfate Flotation of Barite. University of Nevada, Reno, USA; 1984.

12. Han KN, Healy TW, Fuerstenau DW. The Mechanism of Adsorption of Fatty Acids and Other Surfactants at the Oxide-Water Interface. Journal of Colloid and Interface Science. 1973;44(3):407-414.

13. Mizuniwa T, Iwano K, Matsuoka I, et al. Spectrophotometric Determination of Sodium Oleate with Nile Blue .Determination of the amounts of sodium oleate adsorbed on non sulfide Minerals. Journal of the Mining and Metallurgy Institute of Japan. 1977;77(6):435-439.

14. Ananthapadmanabhan KP, Somasundaran P. Acid-Soap Formation in Aqueous Oleate Solutions. Journal of Colloid and Interface Science. 1988;122(1):104-109.

15. Misra M, Mehta RK, Chen S, et al. Physico-chemical Characterization and Flotation of Thorium Contaminated Soil from Kirtland Air Force Base. Preprint 96-150, SME Annual Meeting, Phoenix, Arizona; 1996. p. $11-14$. 